\title{
Kentsel Stres Kavramı ve Kentsel Stresi Azaltmak
}

\author{
Tolga Kayacan $^{1 *}$, Ece Özmen ${ }^{2}$ \\ ${ }^{1 *}$ Şehir Plancis1, Dr. (ORCID: 0000-0003-0818-277X), tolga_kayacan@yahoo.com \\ ${ }^{2}$ Manisa Celal Bayar Üniversitesi, Salihli Meslek Yüksek Okulu, Toptan ve Perakende Satış Bölümü, Emlak ve Emlak Yönetimi Programı, Manisa, Türkiye (ORCID: \\ 0000-0003-0769-9777), ece.ozmen@.cbu.edu.tr
}

(İlk Geliş Tarihi 25 Mart 2021 ve Kabul Tarihi 27 Haziran 2021)

(DOI: 10.31590/ejosat.903252)

ATIF/REFERENCE: Kayacan, T., \& Özmen, E. (2021). Kentsel Stres Kavramı ve Kentsel Stresi Azaltmak. Avrupa Bilim ve Teknoloji Dergisi, (25), 295-305.

\begin{abstract}
$\ddot{\mathbf{O z}}$
Kentleşme sürecine bağlı oluşan düzensiz yapılaşmaya çözüm aranırken, bir yandan yeni kentlilere yerleşim alanları oluşturulmaya devam etmektedir. Ayrıca yaşanan pandemi süreci ile kentlerdeki düzensiz ve yetersiz yapılaşma koşullarının insan sağlığı üzerine olan etkileri de gündeme gelmiştir. Kentlerin de bir taşıma kapasitesi olduğu düşünüldüğünde hem kentler hem de kentliler üzerinde insan sağlığını etkileyecek düzeyde kentsel stres oluşmaktadır. Kentsel stres kavramı dünyada önemli araştırmalara konu olmakla birlikte, ülkemizde genel olarak stres kavramı kullanılmakta, kentsel stres kavram olarak değerlendirilmemektedir. Kent yaşantısının bireyler üzerinde yarattığı stresten genel anlamda bahsedilmekte ve bu stresten kurtulabilmek için bireylerin doğa ile daha çok iletişimde olmaları, spor yapmaları gibi yöntemler önerilmektedir. Bu çalışmada dünyada kentsel stres kavramının hangi boyutlarda değerlendirildiği iki farklı araştırma ile incelenerek, Türkiye'nin en stresli kenti olan İstanbul'daki uygulamaların bu değerlendirme boyutlarına göre hangi noktada olduğu değerlendirilmiştir. Çalışmalarda genel olarak kentsel çevreden kaynaklanan faktörler ve ekonomik faktörlerin değerlendirildiği görülmüştür. Bununla birlikte Türkiye'de stresi azaltmak için genel olarak yeşil alan uygulamaları karşımıza çıkmaktadır. Bu da Türkiye'deki uygulamaların yalnızca kentsel çevreden kaynaklı faktörleri azaltabilecek uygulamalar olduğunu göstermektedir. Kentsel stresin bir kavram olarak değerlendirilmemesi, kentsel strese yol açan tüm faktörlerin tespit edilememesi ve bu faktörlere müdahale edilememesi anlamını taşımaktadır.
\end{abstract}

Anahtar Kelimeler: Kentsel stres, kentsel stres faktörleri, en stresli kentler, kentsel stresi azaltmak, yeşil alanlar.

\section{Urban Stress and Reducing Urban Stress}

\begin{abstract}
As searching for a solution for unplanned settlements in urbanization process, new settlements are being formed for new citizens. Furthermore, the effects of unplanned and inadequate housing conditions on human health came up with the current pandemic situation. Considering the cities have a bearing capacity, urban stress is formed on both cities and citizens that will effect the human health. As urban stress term being an important subject for researches in the world, in Turkey, stress is used as a general term. The general stress formed by the daily urban life on individuals is mentioned and in order to get rid of this stress, suggestions like more communication with nature and doing sports are made. In this paper, it will be reviewed in which dimensions is urban stress is interpreted, through 2 different researches, and how can the practices in Istanbul, the most stressful city of Turkey, be considered within these dimensions. It was seen in the mentioned studies, that factors deriving from urban environment and economical factors were taken into consideration. However in Turkey, we encounter mostly green area implementations in order to reduce stress. This shows us the implementations can reduce urban stress factors only deriving from urban unvironment. Not considering urban stress as a term, causes not being able to determine all factors causing urban stress and not being able to interfere these factors.
\end{abstract}

Keywords: Urban stress, urban stress factors, the most stressful cities, reducing urban stress, green areas.

\footnotetext{
*Sorumlu Yazar: tolga_kayacan@yahoo.com
} 


\section{Giriş}

Birleşmiş Milletler İnsan Yerleşmeleri Programı Dünya Şehirleri 2020 raporuna göre, yaşanan pandemi süreci ile demografik değişikliğin ne ölçüde olacağı bilinmemesine rağmen uzun vadede Dünya'nın kentleşmeye devam edeceği yönündedir. Aynı raporda günümüzde \%56,2 olan kentleşme oranının 2030 yılında \%60,4 oranına yükseleceği tahmini yer almaktadır (UN-Habitat, 2020). Dünya genelinde her bölgenin kentleşmeye devam edeceği ön görüsü kentlerde ve yaşam alanlarında yaşanacak değişimin kaçınılmaz olduğunun göstergesi haline gelmektedir.

Kentleşme ile birlikte artacak nüfus yoğunluğu oluşturduğu çevresel etkiler ile kentlerde stresin artmasında başlıca bir rol oynamaktadır. Evans ve Cohen (1987)'e göre kentsel stresin çevresel kaynaklı nedenleri; giderek artan kent nüfusu ile kentlerde yaşayan insanların kendine ait alanlarının azalması, yetersiz güvenlik ve dengesiz ekonomik koşullardır. Koene (2018)'e göre ise kentsel strese yol açan faktörler daha fazladır. Kentsel çevreden kaynaklanan faktörler, sosyal kaynaklı faktörler, kentlerin durumundan kaynaklı faktörler, sağlık kaynaklı faktörler ve ekonomik kentsel faktörlerdir.

Kentsel stres kavramı bir süredir dile getirilse de, literatürde bu konuda yapılmış çok fazla çalışma bulunmamaktadır. Yapılan bazı çalışmalarda kentsel strese yol açan faktörler genel olarak trafik, insan kalabalığı, çalışma ve uyku süreleri şeklinde değerlendirilmiştir. Bu faktörler ile birlikte "dünyanın en stresli kentleri" listeleri hazırlanmış olup, Türkiye'nin en büyük kenti olan İstanbul'un da bu listede ilk 5 içerisinde yer aldığ 1 görülmüştür.

Yeşil alanların ve doğa ile iletişimin stresi azaltan en önemli faktörler olduğu göz önünde bulundurularak kentlerde yeşil alanların düzenlenmesi stresi azaltmada en yaygın yöntem olarak karşımıza çıkmaktadır. İstanbul'da da bu konuda son dönemlerde atılan önemli adımlar bulunmaktadır. Bu çalışmada kentsel stres faktörleri ve dünyanın en stresli kentleri incelenmiş olup, listede ilk 5'te yer alan İstanbul'da kentsel stresi azaltmak için neler yapıldığı değerlendirilmiştir.

\section{Kentsel Stres Kavramı ve Faktörleri}

Stres, 21. yüzyılın en önemli rahatsızlıklarından biri olarak görülmektedir. Tibbi olarak stres, potansiyel bir tehlikeye karşı vücudun tepki vermesi olarak açıklanabilir. Stresin uzun sürmesi ya da kronik hale gelmesi, ruhsal veya fiziksel rahatsızlık riskini artırmaktadır. Son yıllarda yapılan araştırmalar ise insanlarda stres seviyelerinin kentlerde daha yüksek olduğunu göstermektedir. Kalabalık ortamlarda gürültü ve kirliliğin yanı sıra, çevrenin birey tarafindan daha az kontrol edilebilir hale gelmesi ile, bireylerde stres artmaktadır. Amerikan Psikoloji Derneği (American Psychological Association) verileri ile oluşturulan Şekil 1'e göre kentsel stresin başlica nedenleri arasında para, iş ve ekonomi gelmektedir. Bunları ilişkiler, ailevi sorumluluklar, ailevi sağlık problemleri ve ferdi sağlık endişeleri şeklinde sıralanmaktadır.

\section{Şekil 1. Kentsel stres nedenleri (Koene, 2018 verileri kullanılarak üretilmiştir.)}

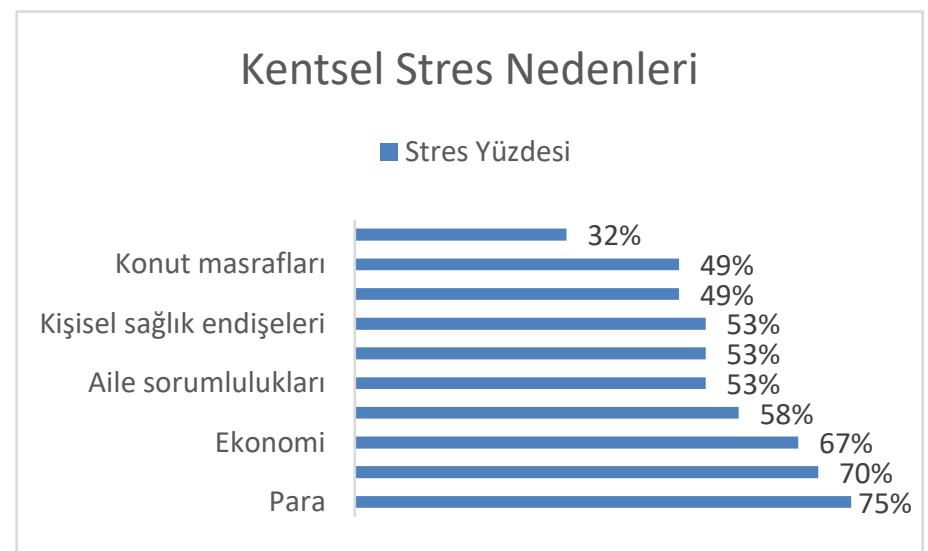

Kentsel stres iki farklı şekilde açıklanabilmektedir. Birincisi insan davranışlarının kent veya çevre üzerinde yarattığ 1 stres olarak tanımlanmaktadır. Örnek olarak kentin kaldırabileceğinden daha hızlı nüfus artışı, hava kirliliği ve toprak kirliliği verilebilir. İkincisi ise kentsel çevrenin insanlar üzerinde yarattığ 1 strestir. Bu şekilde bir kentsel stres tanımının literatürde bulunması oldukça zor olsa da, kentsel stres çevresel uyarıcıların kişinin başa çıkabileceğinden fazla olması durumunda ortaya çıkan stres, çevresel firsatlar ve bireylerin hedefleri arasında ortaya çıkan dengesizlik veya kişinin çevresel talepler ile başa çıkamaması durumunda ortaya çıkan stres şeklinde tanımlanabilir (Koene, 2018).

Kentsel stres, kentleşme dinamiklerinden etkilenen kent ve çevrenin birey ve toplumda oluşturduğu stres faktörleri ile yeniden kentlilerde (toplum) üzerinden oluşturduğu etkilerin yarattığı sonuçtur (Şekil 2). Toplumun hareketliliği de kentleşme dinamiklerine dönüştüğü için bu durum kısır döngü oluşturmaktadır. Bu kısır döngü içerisinde yapılan müdahaleler kentsel stresin azaltılması ve arttırılmasında doğrudan rol oynamaktadır.

Şekil 2. Kentsel Stresin Yarattığ Klsır Döngü

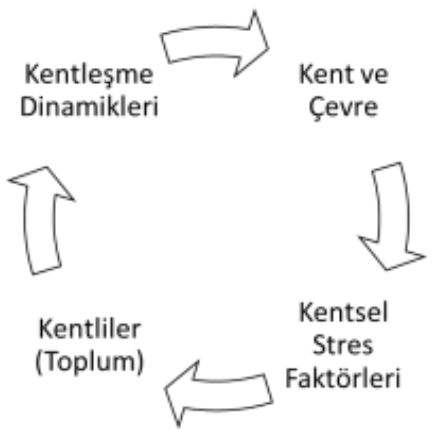

The Guardian gazetesinde yayınlanan bir yazıya göre (Url1), dünyanın farklı mega kentlerinde kentsel strese yol açan pek 
çok ortak faktör bulunmaktadır. Yazıda Kahire, Şangay, Miami ve Mumbai kentleri incelenmiş ve kalabalık, trafik yoğunluğu, gürültü, yeşil alanların eksikliği ve taşımacıllk sistemleri öne çıkan faktörler olarak görülmüştür.

Şekil 3. Şangay kent merkezi 23 milyondan fazla kişiye ev sahipliği yapmaktadır (solda). Kahire dünyanın en gürültülü şehirlerinden biri olarak kabul edilmektedir (săgda). (Url-1)
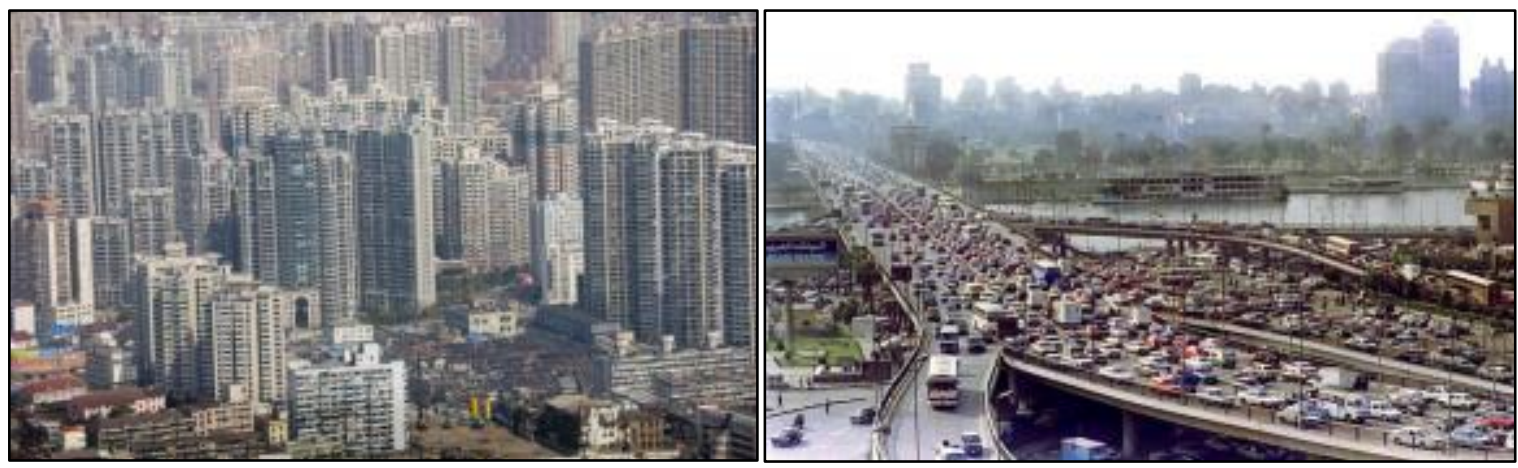

Şekil 4. Mumbai'de kişi başına düşen alan 5 m2'den daha azdır. (Url-1)

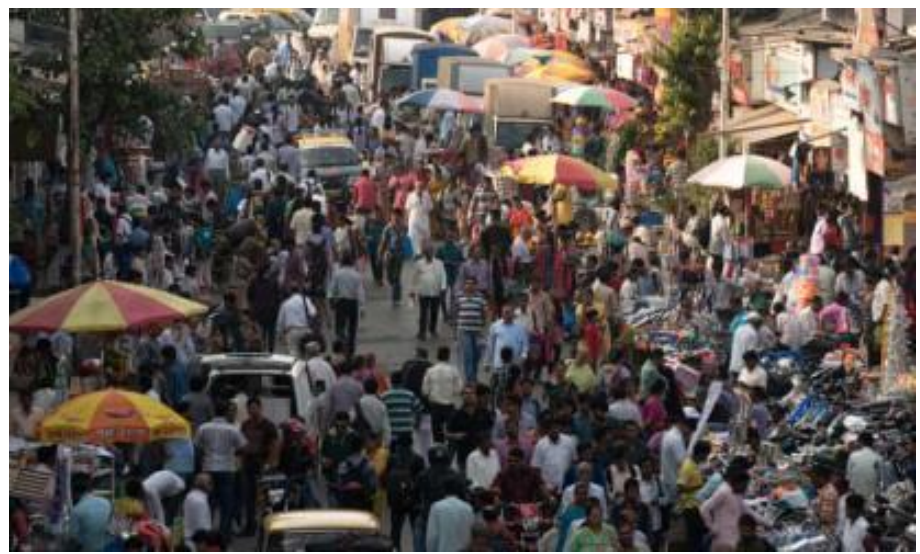

Kentsel strese yol açan faktörler araştırmacılar tarafindan farklı olarak ele alınsa da, bu faktörleri genel olarak kentsel çevreden kaynaklanan faktörler, kentlerin durumundan kaynaklanan faktörler, ekonomik kentsel faktörler, sosyal yaşam kaynaklı faktörler ve sağlık faktörleri olmak üzere beş ana başlıkta toplayabilmek mümkündür (Şekil 5).

$\mathrm{Bu}$ beş temel faktörün alt başlıkları detaylandırıldığında, kentsel çevreden kaynaklı faktörlere örnek olarak kalabalık, etrafa dağılmış çöpler, yüksek katlı yapılaşma, trafik, kazalar ve yeşil alanların varlığı ve ulaşılabilirliği verilebilir. Kentsel yaşam koşullarından kaynaklı faktörler ise hava ve gürültü kirliliği, sıcaklık ve gün ışığı yetersizliği olarak karşımıza çıkmaktadır. Sosyal yaşam faktörleri; cinsiyet eşitsizliği, ırk ayrımcılığı, suç oranları, sosyal destek ağlarının yetersizliğidir. Ekonomik faktörler; işsizlik, sosyal güvence ve satın alma gücü olarak değerlendirilebilir. Sağlık faktörleri ise ruhsal sağlık, fiziksel sağlık, beslenme, egzersiz yetersizliği, obezite ve virüslere açık olma durumlarını kapsamaktadır.
Sekil 5. Kentsel Strese Yol Açan Faktörler (Koene, 2018 verileri kullanılarak üretilmiştir)

\begin{tabular}{|c|c|c|}
\hline $\begin{array}{l}\text { Kentsel Strese Yol } \\
\text { Açan Faktörler }\end{array}$ & 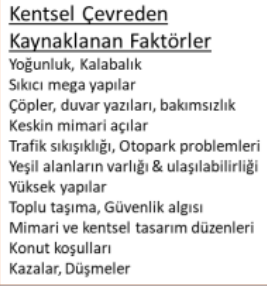 & $\begin{array}{l}\text { Sosyal Yaşam Kaynaklı } \\
\text { Faktörler } \\
\text { Cinsiyet eșitsizlï̌ig } \\
\text { Irk eșitsizliği } \\
\text { Güvenlik hissi } \\
\text { Suç \& Hırsızlık } \\
\text { Sosyal destek ağlarının yetersizliği }\end{array}$ \\
\hline 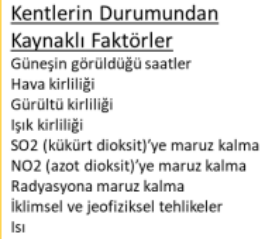 & $\begin{array}{l}\text { Sağı̆ık Kaynaklı Faktörler } \\
\text { Akıl saălı̈̆ı } \\
\text { Fiziksel sağılı } \\
\text { Mikrop, bakteri ve virüslere maruz } \\
\text { kalma } \\
\text { Beslenme } \\
\text { Egzersiz yetersizlig̈i } \\
\text { Obezite }\end{array}$ & $\begin{array}{l}\text { Ekonomik Kentsel Faktörler } \\
\text { Işsizlik } \\
\text { Kişi başına düşsen borç } \\
\text { Sosyal güvenlik } \\
\text { Aile satin alım gūcü }\end{array}$ \\
\hline
\end{tabular}

Yoğun kent yaşamının hangi bölgelerinin daha stresli olduğunun tespit edilmesi de önemli bir tartışma konusudur. Kentin yoğun tempoya sahip kavşak noktalarında kentliler huzursuz ve sinirli hissederken, izole bölgelerinde güvensiz ve yalnız hissedebilmektedir. Kent içindeki yeşil alanlarda insanların sakin ve huzurlu hissettiği gözlenmektedir (Şekil 6). Sosyo-ekonomik statü ya da etnik köken sebebiyle komşularından farklı hissetmek bir kentsel stres faktörü olarak değerlendirilebilmektedir, bu da siklikla izolasyonu deneyimleyen göçmen grupların da kentsel stres yaşadığ 
anlamına gelmektedir. Bu hipotez Almanya'ya göç eden nüfusun çocukları üzerinde test edilmektedir (Url-2).

Şekil 6. Stres ve kent (Url-2)

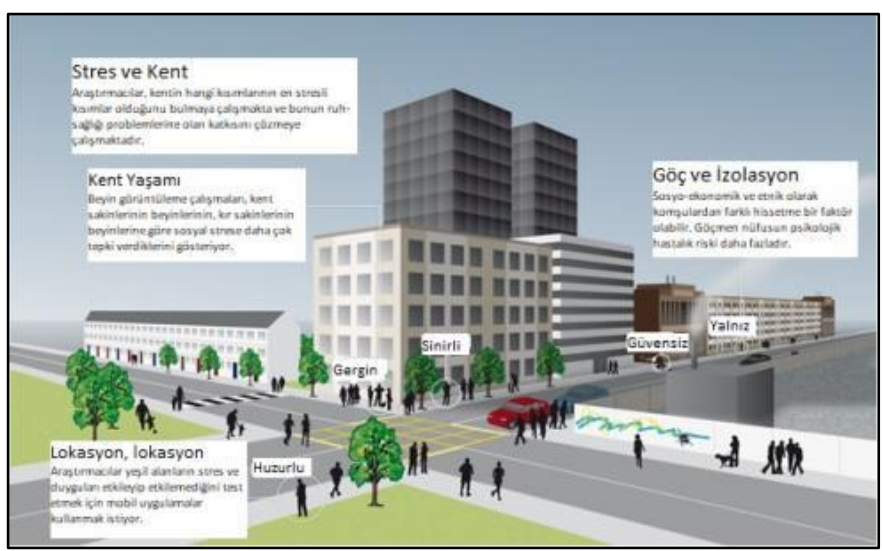

\section{Dünya'da Kentsel Stres ve En Stresli Kentler}

Mayıs 2019'da Dünya Sağlık Örgütü (WHO), tükenmişliği (burnout) Uluslararası Hastalık Siniflandirması'na (ICD-11) dahil etmiştir. Dünya Sağlık Örgütü'ne göre tükenmişlik yönetilemeyen iş stresinden kaynaklanmakta ve şu 3 semptomu göstermektedir (Url-3):

- Düşük enerjili ve tükenmiş hissetmek

- İşyerinde düşük motivasyon ve işten uzaklaşma, ya da bir göreve veya topluma karşı kötümserlik

\section{- İşyerinde düşük performans ve kötü sonuçlar}

Kötü olan durum ise dünya çapında birçok çalışan için bu semptomlar ortak hisleri yansitmaktadir. Yale Duygusal Zeka Merkezi'nin 2018 yılında yaptı̆̆ı bir araştırmaya göre (Moeller ve diğerleri, 2018); Amerika'da her 5 çalışandan 1'i tükenmişlik riski taşımaktadır.

Dünyanın en stresli kentlerini belirlemek için pek çok organizasyon farklı verileri kullanarak listeler oluşturmuşlardır. Bu listelerin geneline bakıldığında pek çok çalışmada bazı ortak verilerin bulunduğu görülmektedir. $\mathrm{Bu}$ ortak verilere örnek olarak haftalık çalışma saatleri, nüfus, trafikte geçirilen zaman, ruhsal sağlık bozukluğu oranı gibi veriler gösterilebilir. Bu çalışmada Savvy Sleeper (www.savvysleeper.org) ve 24/7 Tempo (www.247tempo.com) tarafından gerçekleştirilen çalışma sonrasında oluşturdukları en stresli kentler listeleri incelenecektir. Savvy Sleeper, uyku uzmanları, uyku sağlığ1 araştırmacıları ve yazarlardan oluşan bir organizasyondur. 24/7 Tempo ise 24/7 Wall St. Medya Ağı'na bağlı bulunan bir internet sitesidir.

Savvy Sleeper tarafindan 2020 yılında gerçekleștirilen çalışmada Uluslararası İş Örgütü, Küresel Çalışan Bağlılığı Endeksi, Sağlık Ölçüm ve Değerlendirme Enstitüsü’nün de aralarında bulunduğu 7 itibarlı kaynağa ait veriler ve bir insan kaynakları firması olan Glassdoor tarafından 340.000 çalışan üzerinde yapılan anket sonuçları kullanılmıştır. $\mathrm{Bu}$ listede en stresli kentleri belirlemek için stresli çalışan sayısı, iş yerinde bulunma (fazla mesai, hasta olunsa da işe gelme, vb.), iş yerinde motivasyon düşüklüğü, yıllık çalışma süresi, tatil süresi, 48 saatten uzun çalışan nüfus, ruhsal sağlık bozukluğu yaygınlığ 1 , günlük 7 saatten az uyuyan nüfus ve işten eve dönerken trafikte geçirilen zaman verileri kullanılmıştır. Her bir veri, alındığı kaynaktaki son güncel verilerden alınmıştır. Veriler min-max normalleştirme yöntemi kullanılarak standardize edilmiştir. Minmax normalleştirme değeri 10 ile çarpılarak her veri için $0-10$ arası bir puan elde edilmiştir. 10 puan bir kategorideki en kötü değeri göstermektedir (Url-4). Tablo 1, bu veriler kullanılarak oluşturulan en stresli kentleri göstermektedir. Çalışmada 69 kent belirlenmiş olup, bu çalışmada ilk 30 kent seçilmiştir.

Listede ilk 10 kent içinde Asya ülkeleri ön plana çıkmaktadır. Listenin başında yer alan Tokyo'da işyerinde bulunma ve motivasyon düşüklüğü verilerindeki en yüksek puanlar dikkat çekerken, yine 7 saatten az uyuma verisi de en yüksek puana sahiptir. İkinci sıradaki Mumbai'de ise uzun çalışma saatleri ve trafikte geçirilen zaman yüksek puan almıştır. Üçüncü sırada yer alan Seul'de de benzer şekilde işyerinde bulunma, 7 saatten az uyuma ve tatil süresinin kısalığı strese neden olan etmenlerin başında yer almaktadır.

Avrupa kentlerine bakıldığında, listede 4. sırada ve Avrupa kentleri arasında 1. sırada yer alan İstanbul, stresli çalışan sayısı, haftalık 48 saatten uzun çalışma süresi ve trafikte geçirilen zaman ile stresli kentler listesinde ön plana çıkmaktadır. Avrupa'da 2. sirada, genel listede ise 14. sirada yer alan Londra'da ise günde 7 saatten az uyuma ve trafikte geçirilen zaman etmenleri öne çıkmaktadır. Finansal hizmetler sektöründe ekonomik merkez olarak görülen Londra, bu sektördeki uzun çalışma saatleri, yüksek baskı ve ruhsal sağlık sorunları nedeniyle tablodaki yerini almaktadır.

Tablo genel olarak incelendiğinde Avrupa kentlerinde Asya ve Amerika şehirlerine göre stresin daha az olduğu görülmektedir. Çalışmada, her ne kadar kent ölçeğinde yapılmış olsa da, işverenlere büyük rol düştüğü de belirtilmektedir. İşyerinde bulunma, motivasyon düşüklüğü, düşük tatil süreleri, uzun çalışma saatleri gibi etmenler, işverenlerin aksiyon almasıyla azaltılabilecek etmenlerdir. 
European Journal of Science and Technology

Tablo 1. Savvy Sleeper'ın çalışmasına göre dünyanın en stresli kentleri - 2020 (Url-4).

\begin{tabular}{|c|c|c|c|c|c|c|c|c|c|c|c|c|}
\hline Sira & Şehir & Ulke & $\begin{array}{l}\text { Stresli } \\
\text { Çalıșan }\end{array}$ & $\begin{array}{l}\text { Issyerinde } \\
\text { Bulunma }\end{array}$ & $\begin{array}{l}\text { Işyerinde } \\
\text { Motivasyon } \\
\text { Düşüklüğü }\end{array}$ & $\begin{array}{c}\text { Yıllık } \\
\text { Çalıșma } \\
\text { Saatleri }\end{array}$ & $\begin{array}{c}\text { Tatil } \\
\text { Süresi }\end{array}$ & $\begin{array}{c}48 \text { Saatten } \\
\text { Fazla Çalışan } \\
\text { Nüfus }\end{array}$ & $\begin{array}{l}\text { Ruhsal } \\
\text { Bozukluk } \\
\text { Yaygınlığı }\end{array}$ & $\begin{array}{c}7 \text { Saatten } \\
\text { Az } \\
\text { Uyuyan } \\
\text { Nüfus }\end{array}$ & $\begin{array}{l}\text { Trafikte } \\
\text { Geçirilen } \\
\text { Zaman } \\
\text { (Tek yön) }\end{array}$ & Genel Puan \\
\hline 1 & Tokyo & Japonya & 4.47 & 10 & 10 & 5.13 & 5.44 & 6.25 & 2.94 & 10 & 4.03 & 6.47 \\
\hline 2 & Mumbai & Hindistan & 6.24 & 1.05 & 0 & 10 & 8.42 & - & 5.35 & 6.81 & 9.72 & 5.95 \\
\hline 3 & Seul & Güney Kore & 1.92 & 8.95 & 6.5 & 6.28 & 7.02 & 5.84 & 2.32 & 9.39 & 5.06 & 5.92 \\
\hline 4 & Istanbul & Türkiye & 9.32 & 3.16 & 3.5 & 6.32 & 3.53 & 9.11 & 5.11 & 4.23 & 8.55 & 5.87 \\
\hline 5 & Manila & Filipinler & 5.18 & 4.74 & 3 & 6.21 & 7.06 & 5.65 & 1.23 & 6.81 & 9.74 & 5.51 \\
\hline 6 & Jakarta & Endonezya & 2.2 & 4.74 & 3 & 6.18 & 7.83 & 7.08 & 1.02 & 6.44 & 9.12 & 5.29 \\
\hline 7 & Hanoi & Vietnam & - & 3.68 & 3 & 7.7 & 9.3 & 9.24 & 0 & 8.28 & 1.06 & 5.28 \\
\hline 8 & Taipei & Tayvan & 3.1 & 7.89 & 7 & 5.74 & 8.13 & - & 2 & 5.71 & 2.3 & 5.23 \\
\hline 9 & Los Angeles & $A B D$ & - & 2.11 & 2.5 & 5.14 & 8.53 & 4.06 & 8.48 & 3.37 & 7.14 & 5.17 \\
\hline 10 & Buenos Aires & Arjantin & 3.84 & 3.68 & 3.5 & 4.37 & 6.47 & 5.27 & 6.7 & 5.58 & 6.71 & 5.12 \\
\hline 11 & Sidney & Avustralya & 5.54 & 4.74 & 4.5 & 4.96 & 5.15 & 3.94 & 9.63 & 1.17 & 6.01 & 5.07 \\
\hline 12 & Şikago & $\mathrm{ABD}$ & 7.23 & 2.11 & 2.5 & 5.6 & 7.1 & 4.06 & 8.48 & 3.37 & 5.09 & 5.06 \\
\hline 13 & Kuala Lumpur & Malezya & 4.91 & 5.79 & 3 & 5.53 & 5.81 & - & 2.7 & 7.18 & 5.19 & 5.01 \\
\hline 14 & Londra & UK & 5.44 & 4.21 & 4 & 5.15 & 3.05 & 3.02 & 5.48 & 7.91 & 6.77 & 5 \\
\hline 15 & Bogota & Kolombiya & 5.24 & 2.63 & 2.5 & 6.46 & 6.95 & 8.51 & 0.36 & 5.09 & 7.19 & 4.99 \\
\hline 16 & Pekin & Çin & 6.39 & 3.68 & 2.5 & 5.5 & 8.68 & - & 1.87 & 4.6 & 5.93 & 4.89 \\
\hline 17 & New York & ABD & 5.54 & 2.11 & 2.5 & 5.31 & 6.65 & 4.06 & 8.48 & 3.37 & 5.54 & 4.84 \\
\hline 18 & Johannesburg & Güney Afrika & 3.18 & 1.58 & 2.5 & 6.04 & 6.88 & 5.46 & 3.4 & 9.39 & 5.06 & 4.83 \\
\hline 19 & Auckland & Yeni Zelanda & 5.8 & 3.68 & 4.5 & 4.84 & 4.89 & 3.75 & 10 & 1.04 & 3.76 & 4.7 \\
\hline 20 & Hong Kong & Hong Kong & 5.25 & 3.68 & 2.5 & 5.77 & 6.76 & - & 1.87 & 5.58 & 4.94 & 4.54 \\
\hline 21 & Roma & Italya & 8.62 & 4.21 & 4 & 3.59 & 3.68 & 1.11 & 5.75 & 3.74 & 6.19 & 4.54 \\
\hline 22 & Şangay & Çin & 3.02 & 3.68 & 2.5 & 5.09 & 7.94 & - & 1.87 & 4.6 & 7.59 & 4.54 \\
\hline 23 & Toronto & Kanada & 5.88 & 3.68 & 4 & 4.79 & 5.74 & 2.25 & 6.44 & 2.27 & 5.65 & 4.52 \\
\hline 24 & Bangkok & Tayland & 4.73 & 2.63 & 1.5 & 5.91 & 7.72 & 4.29 & 2.29 & 5.52 & 6.04 & 4.52 \\
\hline 25 & Nairobi & Kenya & 1.97 & 2.63 & 2.5 & 6.2 & 4.19 & 10 & 2.89 & - & 10 & 4.49 \\
\hline 26 & San Francisco & $A B D$ & 2 & 2.11 & 2.5 & 5.48 & - & 4.06 & 8.48 & 3.37 & 6.87 & 4.36 \\
\hline 27 & Miami & $\mathrm{ABD}$ & - & 2.11 & 2.5 & 5.15 & 7.79 & 4.06 & 8.48 & 3.37 & 5.59 & 4.34 \\
\hline 28 & Yeni Delhi & Hindistan & 0 & 1.05 & 0 & 7.03 & 4.63 & - & 5.35 & 6.81 & 9.6 & 4.31 \\
\hline 29 & Atina & Yunanistan & 2.45 & 6.32 & 5 & 5.48 & 3.93 & 1.68 & 6.45 & 3.5 & 3.65 & 4.27 \\
\hline 30 & Mexico City & Meksika & 2.66 & 0 & 0 & 7.44 & 5.26 & 8.73 & 1.28 & 5.21 & 7.71 & 4.25 \\
\hline
\end{tabular}

Dünyanın en stresli kentlerini belirlemek amacıyla bir çalışma yapan bir diğer organizasyon da 24/7 Tempo medya sitesidir. 24/7 Wall St. Medya Ağı üyesi olan site, sağlık, seyahat, yiyecek, yaşam, eğlence ve spor alanlarında araştırmalar yapmakta ve yayınlamaktadır. Dünyanın en stresli şehirleri araştırmasında da değerlendirme faktörleri olarak sağlık durumu, finansal yeterlilik, işe gidiş süresi, konut satın alınabilirliği, haftalık çalışma saatleri ve 2020 Dünya Mutluluk Raporu’na göre (Url-5) mutluluk seviyesi değerlendirilmiştir. $\mathrm{Bu}$ yöntemde de min-max normalleştirme yöntemi kullanılmış ve verilere 0 ile 1 arasında bir değer verilerek her kent için ortalama bir bileşik puan elde edilmiştir (Url-6). Aşağıdaki tabloda 2020 yılında yapılmış bu çalışma neticesinde elde edilmiş en stresli şehirler görülmektedir (Tablo 2).

Tablo 2. 24/7 Tempo araştırmasına göre en stresli şehirler - 2020 (Url-6)

\begin{tabular}{|c|c|c|c|c|c|c|c|c|}
\hline \multirow[t]{2}{*}{ Sira } & \multirow[t]{2}{*}{ Şehir } & \multirow[t]{2}{*}{ Ülke } & \multirow[t]{2}{*}{$\begin{array}{l}\text { Haftalık } \\
\text { Ortalama } \\
\text { Çalışma } \\
\text { Süresi }\end{array}$} & \multirow[t]{2}{*}{$\begin{array}{l}\text { Tek yön } \\
\text { işe gidiş } \\
\text { süresi (dk) }\end{array}$} & \multicolumn{2}{|c|}{$\begin{array}{c}\text { Ruhsal } \\
\text { bozukluk } \\
\text { gösteren } \\
\text { nưfus (\%) }\end{array}$} & \multirow[t]{2}{*}{$\begin{array}{l}\text { Mutluluk Raporu } \\
\text { sıralaması (186 } \\
\text { ülke içinde) }\end{array}$} & \multirow[t]{2}{*}{ Nüfus } \\
\hline & & & & & Kadın & Erkek & & \\
\hline 1 & Hong Kong & Hong Kong & 42 & 42 & $\mathrm{n} / \mathrm{a}$ & $\mathrm{n} / \mathrm{a}$ & 114 & 7,5 mil \\
\hline 2 & Johannesburg & Güney Afrika & 43 & 41 & 12,7 & 12,8 & 120 & $5,8 \mathrm{mil}$ \\
\hline 3 & Kahire & Misir & 36 & 51 & 14,9 & 14,3 & 177 & $20,9 \mathrm{mil}$ \\
\hline 4 & Atina & Yunanistan & 40 & 38 & 16,9 & 14,0 & 121 & 3,2 mil \\
\hline 5 & İstanbul & Türkiye & 45 & 53 & 14,4 & 14,2 & 115 & $14,5 \mathrm{mil}$ \\
\hline 6 & Los Angeles & $A B D$ & 38 & 61 & 18,3 & 16,3 & 31 & $4 \mathrm{mil}$ \\
\hline 7 & Nairobi & Kenya & 44 & 57 & 12,7 & 11,9 & 139 & $4,7 \mathrm{mil}$ \\
\hline 8 & Sao Paulo & Brezilya & 36 & 51 & 15,8 & 13,1 & 53 & $22 \mathrm{mil}$ \\
\hline 9 & Sidney & Avustralya & 38 & 43 & 19,2 & 17,5 & 110 & 4,9 mil \\
\hline 10 & Mexico City & Meksika & 50 & 52 & 11,3 & 10,4 & 38 & $21,8 \mathrm{mil}$ \\
\hline 11 & Buenos Aires & Arjantin & 34 & 48 & 17,6 & 13,7 & 57 & $15,1 \mathrm{mil}$ \\
\hline 12 & Seul & Güney Kore & 44 & 42 & 12,6 & 11,1 & 83 & $10 \mathrm{mil}$ \\
\hline 13 & Bogota & Kolombiya & 45 & 51 & 9,6 & 10,4 & 45 & $11 \mathrm{mil}$ \\
\hline 14 & Auckland & Yeni Zelanda & 37 & 37 & 20,1 & 17,2 & 16 & $1,6 \mathrm{mil}$ \\
\hline 15 & Toronto & Kanada & 37 & 45 & 15,7 & 15,3 & 13 & $6,2 \mathrm{mil}$ \\
\hline 16 & New York & $A B D$ & 39 & 44 & 18,3 & 16,3 & 30 & $8,3 \mathrm{mil}$ \\
\hline 17 & Paris & Fransa & 32 & 41 & 18,3 & 14,3 & 43 & $11 \mathrm{mil}$ \\
\hline 18 & Pekin & Çin & 40 & 46 & 11,3 & 11,4 & 134 & $20,5 \mathrm{mil}$ \\
\hline 19 & Miami & $A B D$ & 39 & 43 & 18,3 & 16,3 & 27 & 471 bin \\
\hline 20 & Barselona & Ispanya & 34 & 30 & 17,8 & 14,5 & 55 & $5,6 \mathrm{mil}$ \\
\hline 21 & Tokyo & Japonya & 38 & 40 & 12,1 & 12,6 & 79 & $37,4 \mathrm{mil}$ \\
\hline 22 & Taipei & Tayvan & 42 & 34 & 11,3 & 11,6 & 47 & 2,7 mil \\
\hline 23 & Melbourne & Avustralya & $n / a$ & 41 & 19,2 & 17,5 & 14 & $5 \mathrm{mil}$ \\
\hline 24 & Budapeşte & Macaristan & 36 & 39 & 11,5 & 11,2 & 103 & $1,8 \mathrm{mil}$ \\
\hline 25 & Şikago & ABD & 41 & 42 & 18,3 & 16,3 & 25 & 2,7 mil \\
\hline
\end{tabular}


Bu tabloya göre 1. sırada yer alan Hong Kong, 1997 y1lında İngiliz egemenliğinden tekrar Çin'e iade edilmiştir. Hong Kong'da kentsel stresin en büyük etmenlerinden biri konut satın alım gücüdür. Bir konutun maliyeti, ortalama bir hane gelirinin 20 katıdır ve bu oran dünyadaki tüm kentler arasında en yüksek orandır. Ayrıca 1997 yılında İngiltere, Hong Kong'u Çin'e iade ederken ekonomik ve basın özgürlügünde komünist Çin'in kabul etmeyeceği şekilde bazı şartlarla iade etmiştir. Bu nedenle Çin'in Hong Kong üzerinde baskısı devam etmektedir. Bu da Hong Kong'ta Çin karşıtı eylemlere sebep olmakta ve ekonomi bu nedenle zarar görmektedir.

2. sıradaki Johannesburg'da ise $\% 28,5$ oranındaki işsizlik, listedeki 190 kent içinde en yüksek orandır. Tüm Güney Afrika'da olduğu gibi Johannesburg'daki yüksek suç oranları da kentsel stresin en büyük etmenlerindendir.

3. sıradaki Kahire, mutluluk raporu sıralamasında en kötü 9. kenttir. Buradaki stresin en büyük kaynağı trafik olarak karşımıza çıkmakta olup, 51 dakika ile işe gidiş süresi 50 dakikanın üzerinde olan listedeki 23 şehirden biridir. Ayrıca ülkedeki politik dengesizlik ve terör olayları da kentte stres yaratan diğer etmenlerdir.

4. sıradaki Atina, 2010 yılında yaşadığı ekonomik kriz sonrasında Avrupa Birliği ve IMF'den aldığı yardımlar sayesinde ayakta durabilmiştir. 2011 yılında ülkenin ekonomisi \%9,1 oranında küçülmüştür. Ayrıca \%17,3 ile Avrupa'nın ikinci en yüksek işsizlik oranına sahiptir. Uzun süren finansal kriz nedeniyle Atinalı girişimciler, kent sakinlerinin stres atmaları için sopalar ile televizyon, klavye, tabak gibi nesneleri parçaladıkları "öfke odaları” oluşturmuştur.

5. sıradaki İstanbul'da ise 53 dakikalık ortalama işe gidiş süresi ile trafik en büyük stres faktörüdür. Bu süre listedeki 13 . en uzun işe gidiş süresidir. Haftalık ortalama 45 saatlik çalışma süresi de listedeki en uzun 6. çalışma süresidir. 2016'daki darbe girişimi, politik olaylar, gözaltılar ve terör olayları da kentte strese neden olmaktadır. Suriye'deki savaştan kaçan göçmenler de ülkede gerginlikyaratmaktadır. İşsizlik oranının \%14'e ulaştığı ülkede Suriyeli göçmenler de iş bulmak için yerel halk ile yarış halindedir.

\section{Kentsel Stresi Azaltmak}

Koene (2018), kentsel stres çalışmasında, stresi azaltmak için 1993 yılında Lazarus'un önerdiği iki yaklaşımı kullanmıştır. $\mathrm{Bu}$ yaklaşımlardan ilki, kişi ve çevre arasındaki ilişkiyi değiştirmeye yönelik olan "problem odaklı çözüm", ikincisi ise olayların etkisini ya da yorumunu değiştirmeye yönelik olan "duygu odaklı çözüm”dür. Koene ilk yaklaşımı "direk yaklaşım", ikinci yaklaşımı ise "dolaylı yaklaşım” olarak kullanmıştır.

Direk yaklaşımda amaç, kentsel strese neden olan etmenlerin ortadan kaldırılması yolu ile kentsel stresin azaltılmasıdır. Örneğin kamusal açık alanlar artırılarak kalabalık etkisi azaltılabilmekte, toplu taşıma araçlarının kullanımı teşvik edilerek trafik azaltılabilmekte, aydınlatma ile sokaklar daha güvenli hale getirilebilmekte, yeşil öğeler ve kent mobilyaları ile sokakların ve caddelerin monotonluğu giderilebilmektedir.

Dolaylı yaklaşımda ise amaç, insanların stres hissini azaltmaya yönelik uygulamalar yaparak kentsel stresi azaltmaktır. Bu uygulamalara örnek olarak özel ve kamusal alanların doğru şekilde ilişkilendirilmesi, kent sakinlerinin rahat ve güvenli şekilde kentte hareket edebilmesi, konut alanlarının yaya yolları ve kaliteli kamusal alanlara bağlanarak insanların sosyalleşmesine olanak sağlanması ve doğal yeşil alanlar ile insanların zihinlerinin rahatlamasının sağlanması verilebilir.

İstanbul için yapılan bir çalışmada (Kaya, 2019), İstanbul'da yaşayanların şehre dair en çok nelerden şikayet ettikleri ortaya konmuştur. Buna göre ilk sırada gürültü kirliliği yer alırken, bunu sırasıyla kentteki ev satış ve kira fiyatları, kent içindeki insan kalabalığı, hava kirliliği, çevre kirliliği, şehir planlaması ve uygulamaları, ahlak ve sosyal kurallara uymama, trafik, çocuk oyun alanlarının azlığı, yeşil alanların yetersizliği, başkaları tarafindan rahatsız edilme, otopark yetersizliği, kaldırımların genişliği ve kent güvenliği izlemektedir.

Türkiye'de kentsel stres bir kavram olarak ele alınmadığı için, kentsel strese yol açan faktörler de ele alınmamaktadır. Büyük kentlerde yaşayan insanların şikayet nedenleri pek çok çalışma ile ortaya konulmakla birlikte, bu nedenleri ortadan kaldırmak ya da etkilerini azaltmak amaçlı çok fazla çalışma görülmemektedir. Örneğin gürültü kirliliği, insan kalabalığı, hava kirliliği, yoğun trafik için yapılan çalışmalar birkaç adet ile sınırlıdır ve bu çalışmalar yeterli olmaktan oldukça uzaktır. Genel yaklaşım, insanları doğa ile, yeşil ile buluşturarak streslerini azaltmayı sağlamaktır. $\mathrm{Bu}$ nedenle yerel yönetimler yaptıkları yeşil alan uygulamalarını ön plana çıkarmaktadır. Oysa yukarıda belirtildiği gibi kentsel strese neden olan pek çok faktör bulunmaktadır. Kentlerdeki stres azaltılmak isteniyorsa, bu faktörlerin tümü değerlendirilmelidir.

İstanbul'da İstanbulluları yeniden yeşil alanla buluşturabilmek, stresten uzaklaşarak sakin ve huzurlu zaman geçirmelerini sağlamak amacıyla bazı projeler yapılmıştır. $\mathrm{Bu}$ projelerin bazılarına kısaca değinilecektir.

\section{- Kemerburgaz Kent Ormanı (Url-7):}

2019 yılının Ekim ayında faaliyete geçirilen Kemerburgaz Kent Ormanı toplamda 5 milyon 526 bin metrekare alana sahiptir. Göktürk ve Kemerburgaz'a yakın konumda olması sebebiyle özellikle hafta sonları İstanbul halkı tarafindan ziyaret edilmektedir. Orman alanı içerisinde bisiklet parkurları, baraj gölü ve dinlenme alanları, futbol sahası, yürüyüş yolları ve kamp alanları bulunmaktadır. El sanatları, uçurtma atölyesi, hayvan ahırları, seyir terasları gibi farklı aktiviteler ile halk, İstanbul'un stresli kent yaşamından uzaklaşma firsatı bulabilmektedir. 
Şekil 7: Kemerburgaz Kent Ormanı haritası (Url-7).

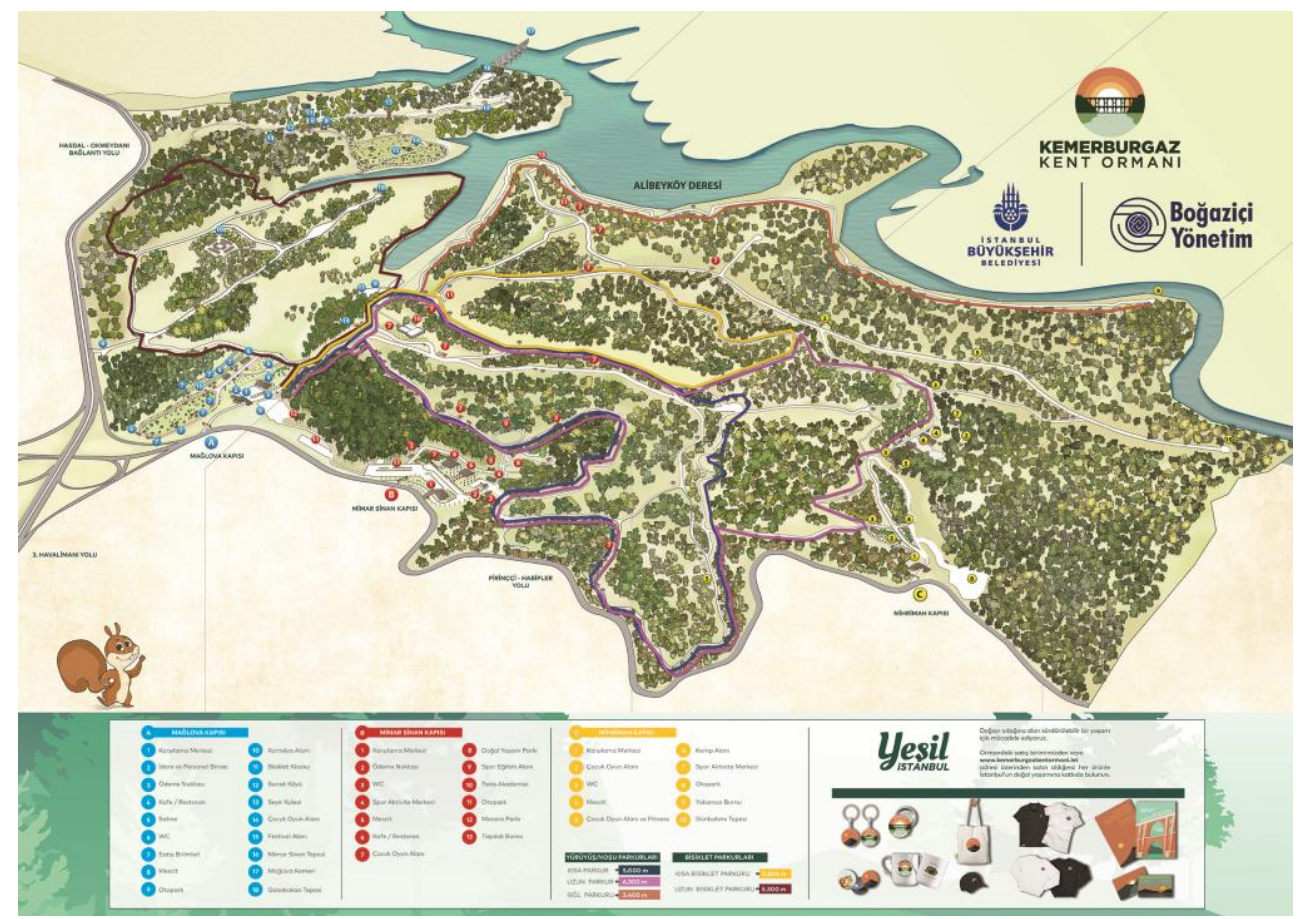

Şekil 8: Kemerburgaz Kent Ormanı motorsiklet parkuru ve macera parkı (Url-7)
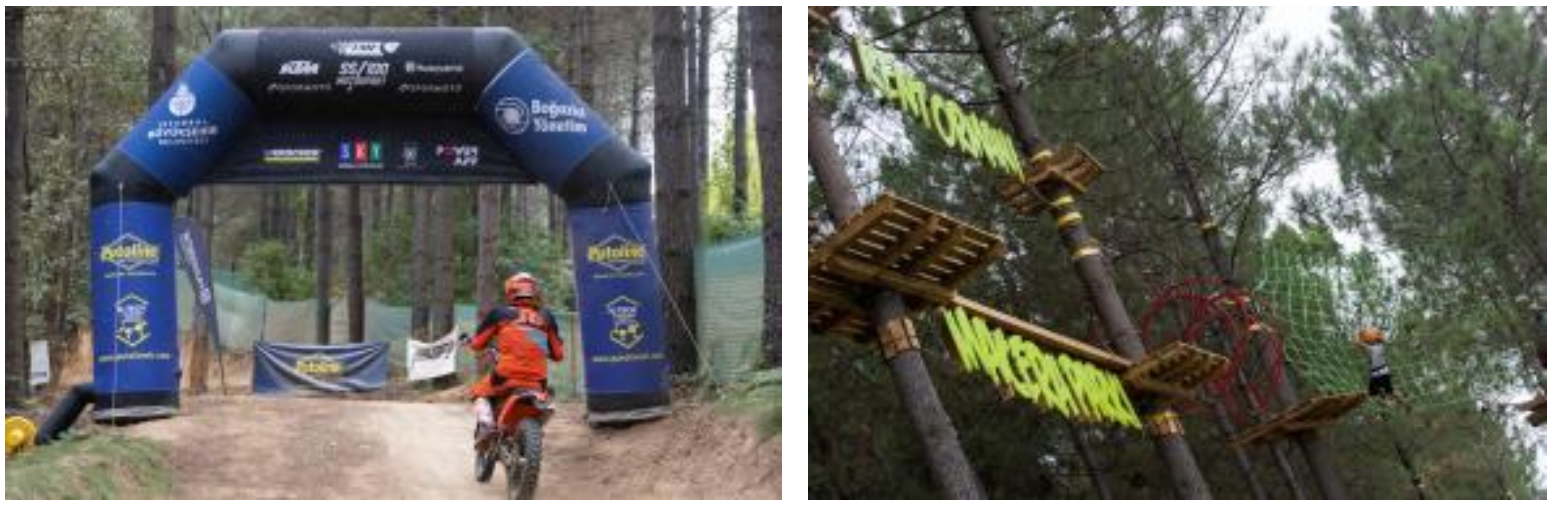

Şekil 9: Kemerburgaz Kent ormanından bazı görüntüler (Url-8)

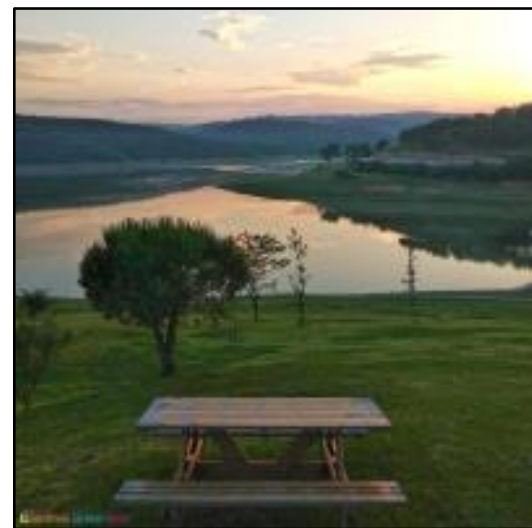

- Beylikdüzü Yaşam Vadisi

Toplamda 6 etaptan oluşacak olan ve Beylikdüzü'nü deniz ile buluşturmayı amaçlayan bir yeşil alan olan Beylikdüzü Yaşam Vadisi projesi, 1 milyon 200 bin metrekarelik bir alana sahip olacaktır. İlk etab1 2017, ikinci etabı ise 2019 y1lında açılan projenin üçüncü etap çalışmalarında da sona gelinmiştir.

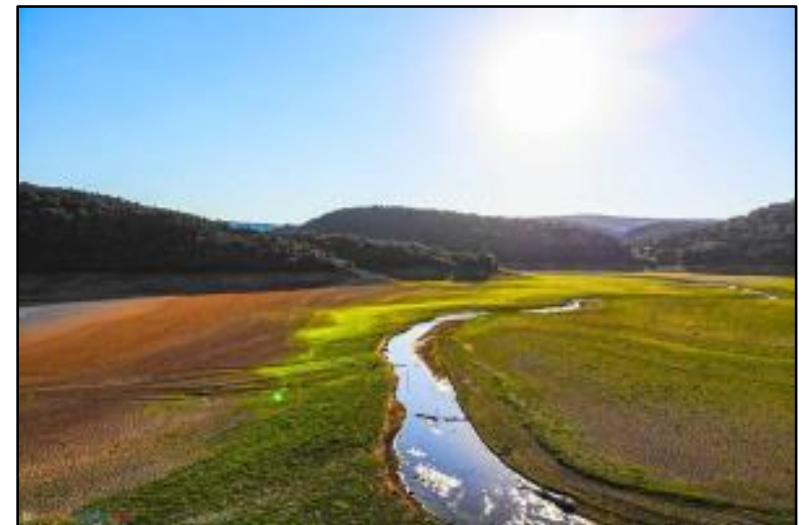

Bu üç etapla birlikte toplamda 800 bin metrekarelik bir alan hizmete açılmış olacaktır. 2021 yılı sonuna kadar 4. ve 5. etapların da tamamlanarak projenin denize ulaşması sağlanmış olacaktır. Projede etkinlik alanları, yürüyüş yolları, spor alanları, okuma bahçesi, yoga bahçesi, botanik atölyesi gibi aktiviteler bulunmaktadır (Url-9). 
Şekil 10: Beylikdüzü Yaşam Vadisi genel bakış (Url-10)

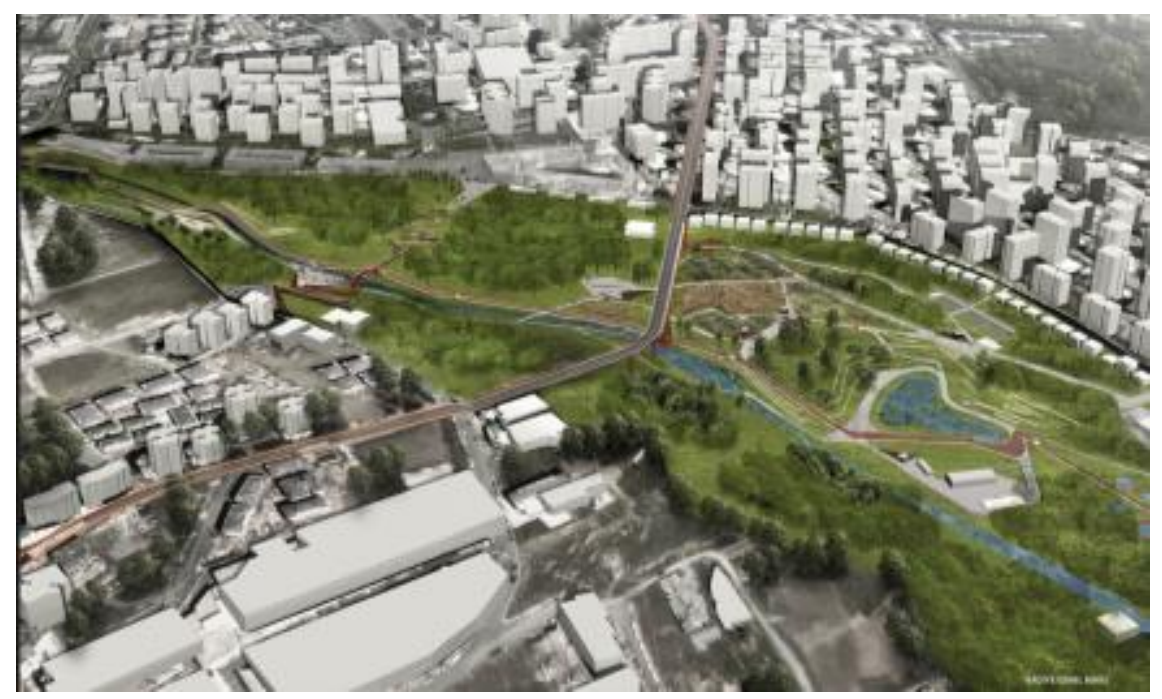

Şekil 11: Beylikdüzü Yaşam Vadisi vaziyet planı (Url-11)

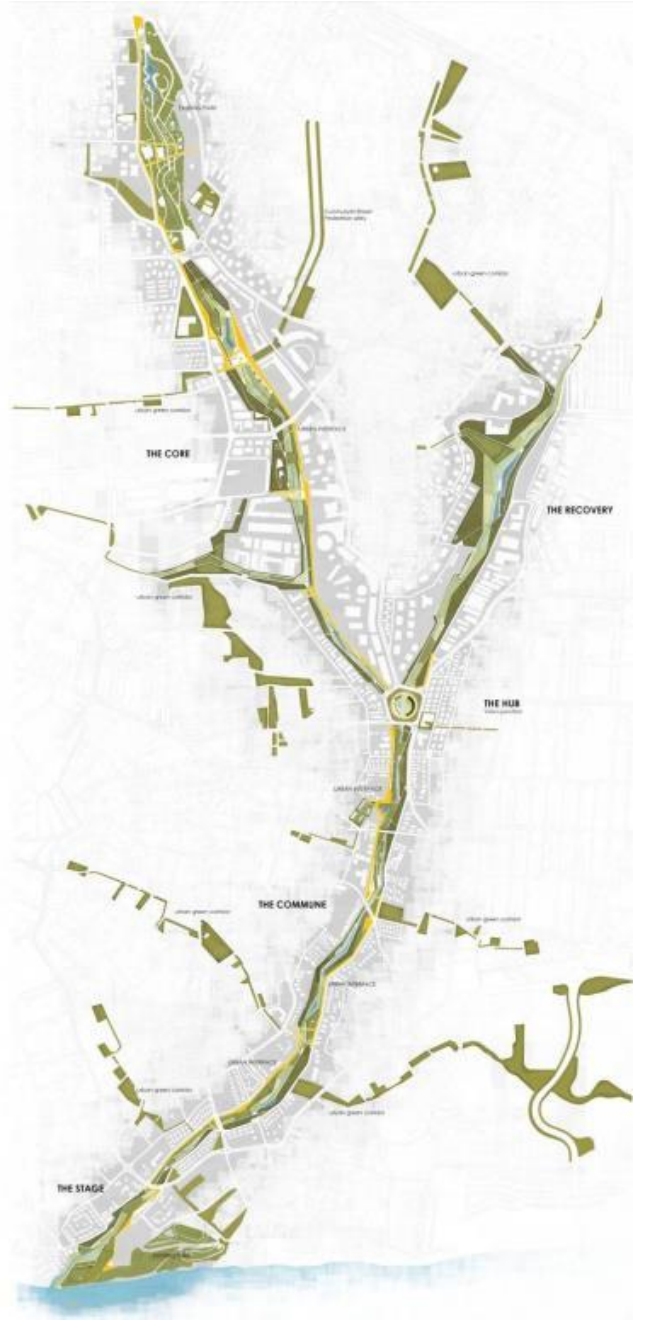

Şekil 11: Beylikdüzü Yaşam Vadisi vaziyet planı (Url-11)

- Beykoz Belediyesi Hobi Bahçeleri

Beykoz Belediyesi tarafindan doğal tarımı teşvik etmek, ilçedeki atıl arazileri kentin stresinden uzaklaşarak toprakla uğraşıp stres atmak isteyen halkın kullanımına sunmak üzere Çubuklu Kiremitdere mevkiinde 2010 yılında hizmete açılmıştır.
20 dönümlük arazi üzerinde kurulan hobi bahçelerinde 50'şer metrekarelik 100 adet bahçe bulunmaktadır. Her bahçe için bir ahşap kulübe, sulama sistemi ve terasların yerleştirildiği hobi bahçelerinin 50 araçlık bir otoparkı, çocuk oyun alanı, yönetimi, güvenliği ve bir kafeteryası bulunmaktadır (Url-12). 
Şekil 12: Beykoz Belediyesi hobi bahçeleri yerleşim planı (Url-13) ve genel görünüm (Url-14)

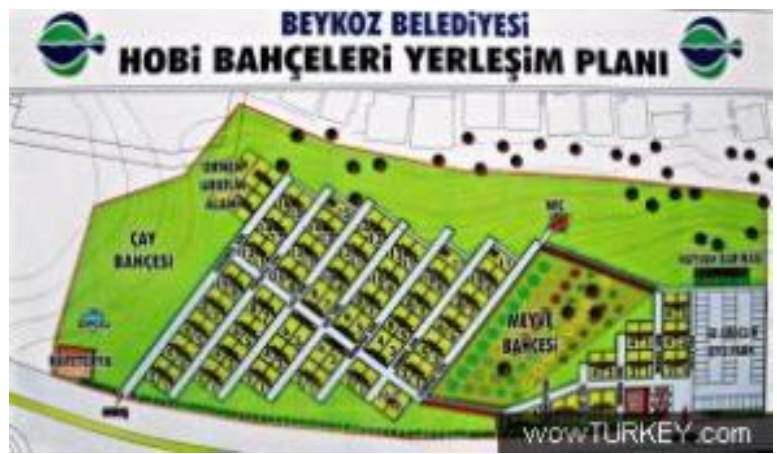

- Çırpıcı Şehir Parkı

2015 yılında Zeytinburnu'nda faaliyete açılan ve 150 bin metrekare alana sahip Çırpıcı Şehir Parkı, Osmanlı döneminin ünlü mesire alanı olan Çırpıcı Çayırı üzerinde kurulmuştur. 1950 'lerden sonra bölgede kurulan sanayi tesisleri nedeniyle bu alan ve alandan geçen dere son derece kirli hale gelmiş, Çırpıcı

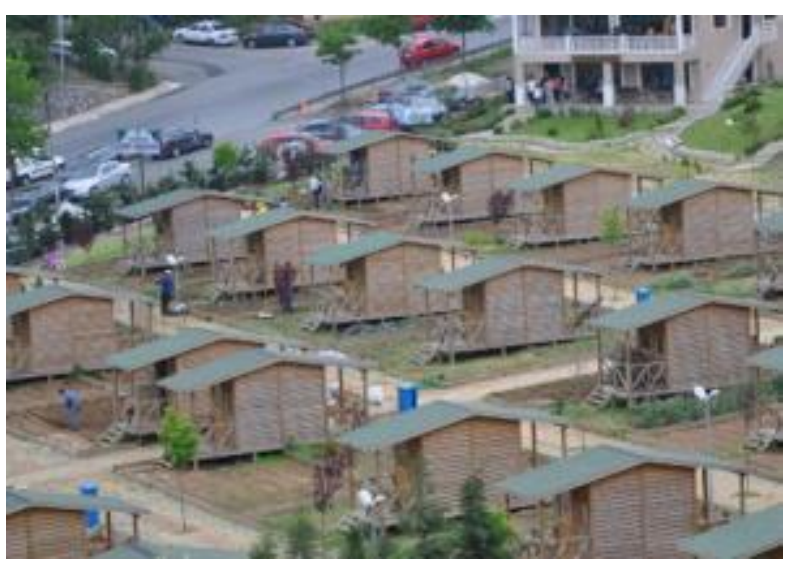

Çayırı da kullanılamaz duruma gelmiştir. Şehir parkı iki etap olarak tasarlanmış, toplam 500 bin metrekare alana sahip olacağ 1 öngörülmüştür. Şehir parkı içerisinde tenis kortları, halı sahalar, basketbol sahaları, buz pisti, piknik alanları, yürüyüş yolları, koşu ve bisiklet parkurları gibi aktiviteler yer almaktadır (Url15).

Şekil 13: Çırpıcı Şehir Parkı (Url-16)

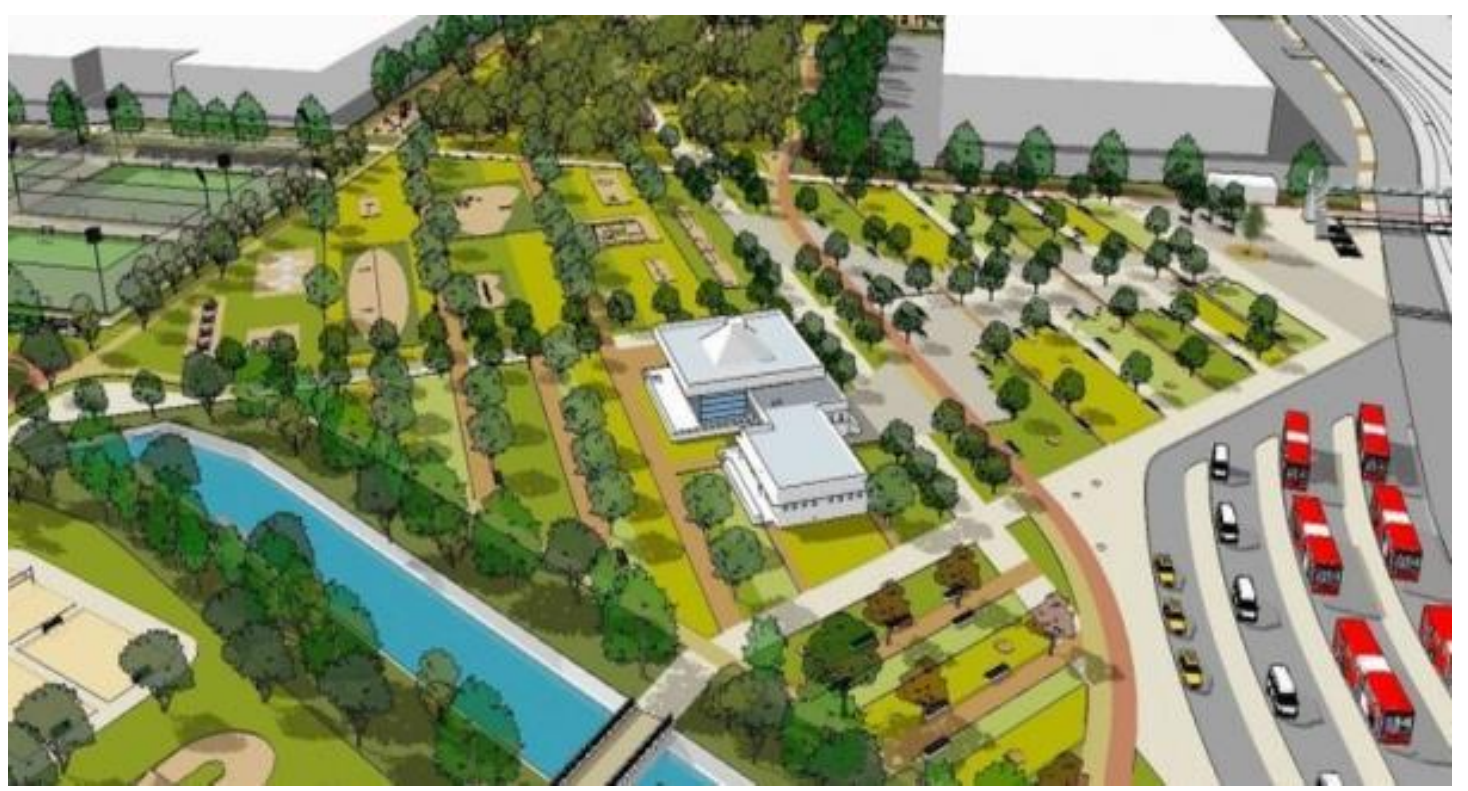

Şekil 14: Çırpıcı Şehir Parkı (Url-17)

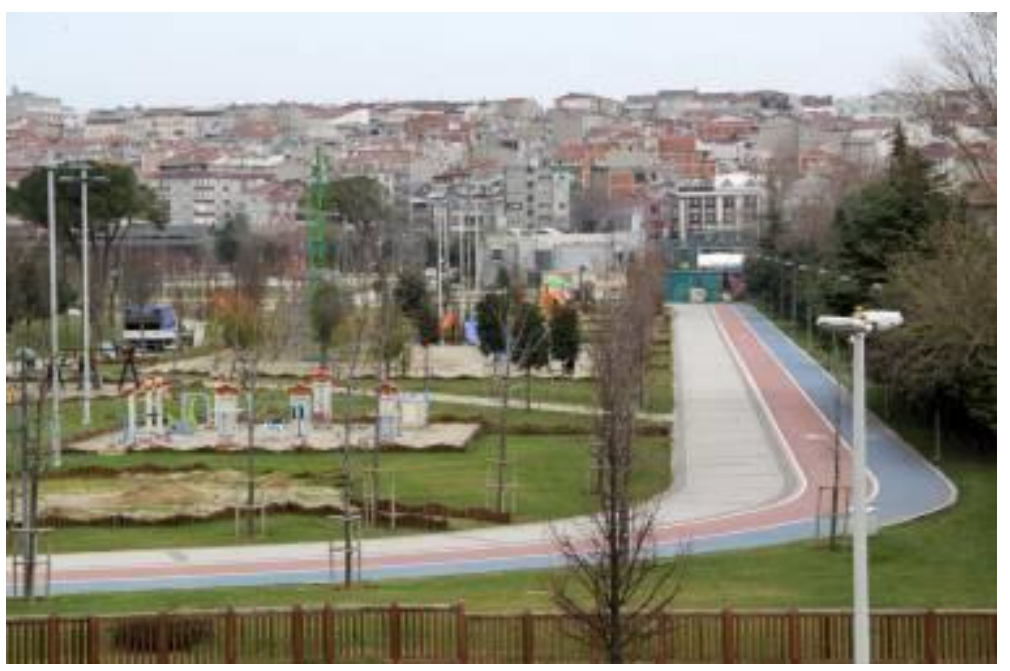




\section{Sonuç}

Kentlerde giderek artan nüfus, kalabalık mekanlara, trafiğe ve gürültü kirliliği gibi durumlara neden olmaktadır. Trafikte geçirilen uzun süreler, araçların ve insanların gürültüsü, kalabalık mekanlarda bulunmak veya buralardan geçmek kentlerde yaşayan insanlarda strese neden olmaktadır. Bununla birlikte uzun çalışma saatleri, az uyuma, tatile gidememe, yeşil alanların kentteki oranının azlığı da bu strese katkı sağlayan diğer etmenlerdir. Günümüzde pek çok metropolde yaşayan insanlar, kentsel stres nedeniyle sağlığından olmakta, hatta hayatını kaybedebileceği seviyelere gelmektedir.

Bununla birlikte literatüre bakıldığında kentsel stres ile ilgili olarak yapılmış çok fazla çalışma bulunmamaktadır. Çalışmada adı geçen iki firma tarafından yapılan çalışmada bazı faktörler değerlendirilerek iki adet liste hazırlanmıştır. Değerlendirilen faktörlere bakıldığında genel olarak iş yerinde çalışma süreleri, işe giderken trafikte geçirilen zaman, uykuda geçirilen zaman, yılda tatile harcanan zaman gibi faktörlerin değerlendirildiği görülmektedir. Buradan yola çıkılarak bu iki çalışmada kentsel çevreden kaynaklı faktörler ve ekonomik faktörlerin değerlendirmeye alındığı sonucuna ulaşılmaktadır. Hazırlanan listelere göre dünyanın en stresli kentleri doğal olarak nüfusu yoğun olan metropoller olarak karşımıza çıkmaktadır. Özellikle Asya ve Güney Amerika'daki metropoller bu listede ilk sıralardadır. Türkiye'nin en büyük kenti olan İstanbul da her iki listede ilk 5 'in içinde yer almaktadır.

Ancak kentsel strese neden olan pek çok faktör bulunmaktadır. Kentsel stresin azaltılması için bu faktörlerin tümüyle değerlendirilmesi gerekmektedir. Gürültü kirliliği, insan kalabalığı, yoğun trafik, çevre kirliliği, sosyal donatı alanlarının yetersizliği, hava kirliliği, kentteki güvenlik önlemlerinin yetersizliği, konut fiyatları, cinsiyet eşitsizliği gibi pek çok stres faktörü bulunmaktadır. Ancak bu faktörlere özellikle ülkemizde yeterli önem verilmemekte olup, genel olarak kent sakinlerinin doğa ve yeşil alanlar ile etkileşimini sağlayarak, kentsel çevreden kaynaklanan kentsel stres faktörlerini azaltma yöntemi tercih edilmektedir. Ancak, bu yöntem anlık stres azaltılmasında etkili olmakla birlikte kalıcı çözümler sağlamamaktadır. Gürültü kirliliğinin azaltılması, caddelerin ve kaldırımların doğru tasarlanarak aşırı kalabalığa neden olmaması, doğru planlama çalışmaları ile yeşil alan ve donatı alanlarının, insanların sosyalleşebileceği alanların artırılması, toplu taşımanın daha etkin kullanımının sağlanarak trafiğin azaltılması gibi kalıcı yöntemler ile birlikte kentsel stresin azaltılmasında kalıcı çözümler söz konusu olabilecektir. Bu noktada merkezi yönetim tarafından çeşitli önlemler alınarak özellikle sosyal yaşam kaynaklı faktörlerin, sağlık kaynaklı faktörlerin ve ekonomik faktörlerin azaltılması sağlanabilecektir. Örneğin stres nedeniyle sağlığı bozulan kent sakinlerine destek olunması, sağlığ bozan faktörlerin ortadan kaldırılması, cinsiyet eşitsizliğinin kaldırılması, suç oranlarının azaltılması ve kentlerin yeterli olacak şekilde güvenliğinin sağlanması, konut fiyatlarının düzenlenmesi, istihdam yaratılarak işsizliğin azaltılması gibi pek çok yaklaşım ile kentsel stresin azaltılması mümkündür.

Kentsel stresin azaltılmasında en etkili yöntemlerden biri olarak karşımıza çıkan yeşil alanlar ve doğa ile iletişim, kentlerde yerel yönetimlerin en çok başvurduğu yöntemdir. Ancak büyük kentlerde arazinin değerli olması nedeniyle genel olarak bu arazilerin yeşil alan için ayrılması önünde engel teşkil etmektedir. Kentsel rant nedeniyle bu alanlar daha çok konut ya da ticari alan gibi yoğun kullanımlara ayrılmaktadır. Bu nedenle kentlerde yeşil alanlar daha çok mahalle aralarına sıkışmış küçük parklar olarak öne çıkmaktadır.

İstanbul'da yapılan projelere genel olarak bakıldığında, daha büyük ölçekli yeşil alanların şehir merkezine uzak bölgelerde konumlandırıldığı görülmektedir. $\mathrm{Bu}$ noktalara ulaşım zor olduğundan, genelde o bölgede yaşayan halkın faydalanabileceği projeler olmaktadır. Kentin merkezi noktalarında yaşayan halkın ancak özel araç ile ulaşabileceği noktalarda gerçekleşen projelerdir. $\mathrm{Bu}$ da özellikle düşük gelir grubunun bu alanlara ulaşımını oldukça zorlaştırmakta, bu kesimin kentsel stresini azaltmada rol oynayamamaktadır. Çalışmada örnek olarak gösterilen projelerin seçilme nedenleri, geniş bir nüfusa hitap edebilecek nitelikte ve büyüklükte gerçekleştirilmiş olmalarıdır. Bununla birlikte bu alanlarda geçirilecek zamanın ve gerçekleştirilebilecek aktivitelerin kentsel stresi azaltabilecek nitelikte olabilmesidir. Yalnızca bir parkta oturarak yeşil öğelere bakılarak stresin azalması değil, farklı aktiviteler ile bireylerin meşgul olması ve strese neden olan faktörleri bir süreliğine de olsa unutabilecek olması, projelerin değerlendirilmesinde önem kazanmıştır.

Öte yandan gerçekleştirilen projelerde stres kavramı genel anlamıyla kullanılmakta, kentsel stres kavram olarak çok geçmemektedir. Ayrıca yeşil alanların sayısının ve büyüklüğünün artırılması kentsel stresi azaltacak önemli bir adım olsa da, tek başına yeterli olmayacaktır. Trafikte geçirilen uzun zamanlar, uzun çalışma saatleri, kentlerdeki yoğun kalabalık da çözüm bulunması gereken diğer faktörlerdir. Özellikle toplu taşımanın yetersizliği ya da yeterince teşvik edilememesi sonucu artan özel araç kullanımı ile birlikte gelen yoğun trafik, kentsel strese neden olan en önemli etkenlerden biridir. Yerel yönetimler tarafından bu konuda da yeterli çözüm önerileri getirilmelidir.

Bir kentte yaşayanların kentsel stresini azaltabilmek için öncelikle o kentteki strese neden olan etkenler tespit edilmeli ve bu etkenleri ortadan kaldırabilecek ya da azaltabilecek çalışmalar yapılmalıdır. Genel varsayımlarla ve tek başına çözüm olması umuduyla yapılan çalışmalar uzun vadede getiri sağlamayacaktır.

\section{Kaynakça}

Evans, G., Cohen, S. 1987. Environmental Stress, Handbook of Environmental Psychology, Vol.1, p. 571-610, WileyInterscience Publication.

Kaya, F.Ş., 2019. Kent Yaşamı Memnuniyeti, Stresle Başa Çıkma ve Yaşam Doyumu İlişkisi: İstanbul Örneği, Stratejik ve Sosyal Araştırmalar Dergisi, Vol 3 Issue 2, p 325-342.

Koene, M., 2018. Urban Stress, Research into the Reduction of Urban Stress Through Urban Design, Master Thesis, TU Delft.

Moeller, J, ve diğerleri, 2018. Highly Engaged But Burned Out: Intra-individual Profiles in the US workforce, Yale Center for Emotional Intelligence and Yale Child Study Center, Yale University, U.S.A.

UN Habitat, 2020. World Cities Report 2020: The Value of Sustainable Urbanization.

Url-1: https://www.theguardian.com/cities/2015/oct/08/whereworld-most-stressful-city-urban-life-depression-anxiety, erişim tarihi: 01.02.2021

Url-2: https://www.nature.com/news/stress-and-the-city-urbandecay-1.11556, erişim tarihi: 05.02.2021 
Url-3:https://www.who.int/news/item/28-05-2019-burn-out-anoccupational-phenomenon-international-classification-ofdiseases, erişim tarihi: 01.02.2021

Url-4: https://savvysleeper.org/cities-with-highest-burnout/ erişim tarihi: 01.02 .2021

Url-5: https://happinessreport.s3.amazonaws.com/2020/WHR20_Ch3.pdf ， erişim tarihi: 07.02.2021

Url-6: https://247tempo.com/the-worlds-most-stressed-outcities/7/, erişim tarihi: 07.02.2021

Url-7: https://kemerburgazkentormani.ist/ , erişim tarihi: 11.02 .2021

Url-8: https://gezilmesigerekenyerler.com/kemerburgaz-kentormani, erişim tarihi: 11.02.2021

Url-9: $\quad$ https://www.harmonigd.com.tr/tr/haber/beylikduzuyasam-vadisi-4-etap-calismalari-basladi/ , erişim tarihi: 11.02.2021

Url-10: www.arkiv.com.tr, erişim tarihi: 11.02.2021

Url-11: https://www.yalin-mimarlik.com/projeler/beylikduzuvadi, erişim tarihi: 11.02 .2021

Url-12: https://www.haberler.com/beykoz-da-hobi-bahcesiacildi-2263892-haberi/, erişim tarihi: 15.02.2021

Url-13: http://wowturkey.com/forum/viewtopic.php?t=104918 , erişim tarihi: 15.02.2021

Url-14: https://www.yesilist.com/istanbulun-11-hobi-bahcesi/ , erişim tarihi: 15.02.2021

Url-15: http://www.zeytinburnu.istanbul/Haberler/IstanbulunEn-Buyuk-Parki-Zeytinburnunda-Acildi , erişim tarihi: 16.02.2021

Url-16: https://www.yeniemlak.com/zeytinburnu-cirpici-kentparki-acildi-3459-diger-haberler, erişim tarihi: 16.02.2021

Url-17: http://www.avrupaparkbahceler.com/ , erişim tarihi: 16.02.2021 